Canadian

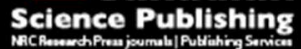

Canadian Journal of Forest Research Revue canadienne de recherche forestière

\title{
Spatial and temporal dynamics of the soil charcoal pool in relation to fire history in a boreal forest landscape
}

\begin{tabular}{|r|l|}
\hline Journal: & Canadian Journal of Forest Research \\
\hline Manuscript ID & cjfr-2016-0233.R1 \\
\hline Manuscript Type: & Article \\
\hline Complete List of Authors: & $\begin{array}{l}\text { Kasin, Isabella; Norwegian Environment Agency } \\
\text { Ellingsen, Vanessa; Norwegian University of Life Sciences, Department of } \\
\text { Ecology and Natural Resource Management } \\
\text { Asplund, Johan; Norwegian University of Life Sciences, Department of } \\
\text { Ecology and Natural Resource Management } \\
\text { Ohlson, Mikael; Norwegian University of Life Sciences, Department of } \\
\text { Ecology and Natural Resource Management }\end{array}$ \\
\hline Keyword: & $\begin{array}{l}\text { charcoal age, charcoal amount, charcoal degradation, forest fire history, } \\
\text { black carbon }\end{array}$ \\
\hline \multicolumn{2}{|l}{} \\
\hline
\end{tabular}




\section{Spatial and temporal dynamics of the soil charcoal pool in relation}

\section{2 to fire history in a boreal forest landscape}

3 Isabella Kasin ${ }^{1}$, Vanessa Marie Ellingsen, Johan Asplund and Mikael Ohlson*

4

5 Norwegian University of Life Sciences, Department of Ecology and Natural Resource

6 Management, P.O. Box 5003, NO-1432 Ås, Norway

7 e-mail addresses: isabella.kasin@miljodir.no; vanessa_me@live.no; johan.asplund@nmbu.no;

8 mikael.ohlson@nmbu.no

9

$10 *$ Corresponding author

11 Norwegian University of Life Sciences, Department of Ecology and Natural Resource

12 Management, P.O. Box 5003, NO-1432 Ås, Norway

13 e-mail: mikael.ohlson@nmbu.no; telephone: +4767231757; fax: +4764965801

14

$15{ }^{1}$ Present address: Norwegian Environment Agency, P.O. Box 5672 Sluppen, NO-7485

16 Trondheim, Norway

17 
18 Abstract: Charcoal pools in boreal forest soils constitute considerable amounts of slow cycling

19 organic matter that is important in the global carbon cycle. However, these pools are

20 characterized by spatio-temporal variations that are not well understood. Here, we have analyzed

21 the charcoal pool in 100 soil samples to determine charcoal stock species origin, and how the

22 size and age of this pool varies across different spatial scales in a Norwegian boreal forest

23 landscape including forests that differ in terms of tree-species composition, tree density and

24 recent fire histories. The size of the charcoal pool was site-specific and highly variable - ranging

25 from 0 to $2108 \mathrm{~g} \mathrm{~m}^{-2}$. Geostatistical analyses showed that the charcoal pool was only weakly

26 spatially structured at fine meter scales and between site scales ( $\sim 100$ meter scale).

27 Unexpectedly, there was no significant relationship between the amount of charcoal and

28 contemporary forest composition and density, although there was proportionally more charcoal

29 from broad leaved trees in today's Scots pine forests than in the Norway spruce forests. When

30 relating this information to the fire history, the results indicate that charcoal is lost at a millennial

31 timescale.

32

33 Key words: black carbon, charcoal age, charcoal amount, charcoal degradation, forest fire

34 history, pyrogenic carbon 
Introduction

Charcoal derived from forest fires is an important part of the pyrogenic and slow cycling fraction of soil organic matter. Due to its importance in the global carbon cycle, pyrogenic black carbon has received much research attention in recent years (Lehmann et al. 2008; Schmidt et al. 2011; Santin et al. 2016). Its functional ecological role has also been acknowledged as fresh

41 charcoal is known to enhance ecosystem productivity (Lehmann et al. 2011). This is also the

42 case in boreal forests (Zackrisson et al. 1996), in which large amounts of charcoal are

43 continuously produced as 5-15 million hectares of boreal forest are consumed by fire annually

44 (Flannigan et al. 2009; Soja et al. 2007). Wildfire production and deposition of macroscopic

45 charcoal is local and highly variable across fine spatial scales (Ohlson and Tryterud 2000).

46 Despite this, spatial and temporal dynamics of this slow cycling soil carbon pool are not fully

47 understood (Schmidt et al. 2011; Santin et al. 2016). For example, some studies show that boreal soil charcoal is truly recalcitrant as it has persisted ever since early Holocene (Couillard et al.

49 2013; de Lafontaine and Asselin 2011), while other studies indicate that charcoal is lost through

50 various means of degradation since the size of the charcoal pool present in boreal soils is smaller

51 than what could be anticipated on the basis of our knowledge about charcoal production and fire

52 return intervals (Czimczik et al. 2005; Ohlson et al. 2009; Ohlson and Tryterud 2000).

Soil charcoal analysis is a valuable tool in paleoecological research and has for example

54 been used to study disturbance patterns (Gavin 2003), climate change and past tree line positions

55 (Talon 2010), fire regimes and forest- and fire history (Carcaillet 1998; Lertzman et al. 2002;

56 Talon et al. 2005; Touflan et al. 2010). When investigating the dynamics of the soil charcoal

57 pool, the spatial dimension does not pose the greatest challenge, as macroscopic charcoal

58 (longest axis $\geq 0.5 \mathrm{~mm}$ ) is a reliable and spatially precise proxy for in situ fire (Clark 1988;

59 Ohlson and Tryterud 2000; Patterson et al. 1987; Touflan and Talon 2009; Touflan et al. 2010). 
60 However, it should be mentioned that macroscopic charcoal may be transported over longer

61 distances in large high-intensity fires (Tinner et al. 2006), and secondary transport may occur

62 through overland flow (Scott 2010). Grasping the temporal dimension is more difficult since it

63 often depends on the soil charcoal stock itself, which may be incomplete due to degradation by

64 recurring fires (Kane et al. 2010; Zimmermann et al. 2012, but see Tinkham et al. 2016).

65 Additionally, temporal resolution is further limited through the inbuilt age of the charcoal (Gavin

66 2001; Ohlson et al. 2009) and radiometric errors (Gavin 2001; Stuiver and Reimer 1993). To

67 support charcoal analysis as a tool to reconstruct past fire activity, information can be derived

68 from stand age- and tree ring analysis, but these cover comparatively short time periods (Gavin

69 et al. 2003a; Kasin et al. 2013). In contrast, lake sediments can provide long-term information,

70 but due to regional source areas, these charcoal records are spatially imprecise (Clark 1988;

71 Higuera et al. 2007). On the other hand, small peat hollows may provide spatially precise long-

72 term information (Higuera et al. 2005; Jacobson Jr and Bradshaw 1981), but these archives are

73 often scarce and characterized by a highly patchy distribution in the forest landscape, and can not

74 be used to reconstruct a picture of past fire activity that is representative on a landscape-scale.

75 Here we compare the information from charcoal analysis of 100 soil samples with the

76 present forest structure and composition in a Norwegian boreal forest landscape with a known

77 Holocene fire history. The fire history of the sites and major vegetation changes (e.g. the local

78 establishment of Norway spruce (Picea abies (L.) Karst.) have been described previously by

79 combining tree-ring- and peat soil analyses (Blanck et al. 2013; Kasin et al. 2013; Storaunet et al.

80 2013). In these studies, the fire history over the last 600 years has been reconstructed with spatial

81 and temporal accuracy through dendrochronological dating of 736 fire scars. During the last 600

82 years, periods with longer (about 80 years) or shorter (about 20-40 years) fire return intervals 
83 were determined, but the total number of fires affecting our study sites did not differ significantly

84 among the sites. In a longer Holocene time perspective, charcoal records from four peatlands

85 bordering our present study sites reached back to ca. 9000 calibrated radiocarbon year before

86 present (cal. yr BP), see Kasin et al. (2013). Moreover, these records revealed millennial fire

87 activities at all sites and that these activities were characterized by large temporal variations. The

88 same charcoal records also showed that the local site specific establishment of Norway spruce

89 range from about 520 to 1950 cal. yr BP. Norway spruce invaded Northern Europe in the late

90 Holocene, and is a recent forest dominant in Norway (Giesecke and Bennett 2004; Seppä et al.

91 2009; Tallantire 1972). In our study, the local establishment of Norway spruce is of great interest

92 as it has been shown to affect fire regimes by reducing local fire frequency and severity (Ohlson

93 et al. 2011). However, all our study sites have been affected by fire after the local spruce

94 establishment (Kasin et al. 2013).

95 The main aim of this study is to better understand what factors that determine the

96 dynamics of the mineral soil charcoal pool. More precisely, we wanted to know whether the size

97 and spatial variation of the charcoal pool differed among sites and if its species composition and

98 age could be explained by the tree-ring derived fire history and/or the contemporary forest

99 composition.

100

101 Material and Methods

102 Study area

103 The study area $\left(60^{\circ} 02^{\prime} \mathrm{N}, 09^{\circ} 26^{\prime} \mathrm{E}\right)$ has an area of about $1 \mathrm{~km}^{2}$ and is situated in the

104 Trillemarka - Rollagsfjell Nature Reserve in the mid-boreal vegetation zone in south east

105 Norway (Moen 1999 and Figure 1). The bedrock is characterized by granites and gneisses of 
106 Precambrian origin, forming north-south extending ridges with deposits of richer moraine

107 material on east-facing slopes. The elevation range from 400 to $650 \mathrm{~m}$ a.s.l. with the climate

108 characterized as intermediate oceanic - continental with rather warm summers (July mean $14.7^{\circ} \mathrm{C}$

109 ) and cold, snow-rich winters (January mean $-7.5^{\circ} \mathrm{C}$ ) (Rollag meteorological station,

110 Norwegian Meteorological Institute (2012)). Norway spruce (P. abies) forests dominate the more

111 nutrient rich moraine slopes. The eastern and central areas between the slopes are characterized

112 by mires and nutrient poor Scots pine (Pinus sylvestris L.) forests.

113

114 Sample sites and procedure for soil sampling

115 In October 2010 we selected four $2500 \mathrm{~m}^{2}$ sites for soil sampling (Figure 1), two in

116 spruce - dominated forests (S1 and S4), and two in pine- dominated forests (S2 and S3). Within

117 each site, we subjectively located five blocks $(5 \times 10 \mathrm{~m})$ in order to cover the variation in

118 vegetation and topography. Five soil samples were collected at random positions in each block,

119 using a restricted random sampling procedure that is proven to be efficient (Økland 1996; Ohlson

120 et al. 2009) and our sampling procedure yielded a total number of 100 samples (25 at each site).

121 Positions in peat-filled depressions or on naked bedrock were discarded. Soil sampling was

122 conducted using a steel cylinder $(50 \mathrm{~cm}$ long, inner diameter $5.8 \mathrm{~cm})$, with each sample

123 containing the entire organic layer and a few centimeters of the underlying mineral soil. As a

124 result, sample depth and volume varied with the thickness of the organic layer $(2-50 \mathrm{~cm})$. The

125 sampling sites were situated on mineral soil in forests adjacent to the mires from which peat

126 samples had been collected earlier, and where the fire history has been described on the basis of

127 the dated charcoal record from the peat samples (Kasin et al. 2013) and dendrochronological

128 analysis of fire scars (Blanck et al. 2013; Storaunet et al. 2013). 
The spruce- and pine forests where the soil samples were collected had a vegetation

130 composition typical for the region (plant names follow Lid and Lid (2005)). The forest floor at

131 spruce forest site S1 was covered by the dwarf shrubs Calluna vulgaris, Vaccinim myrtillus, $V$.

132 vitis-idaea and Empetrum nigrum together with feather mosses. P. sylvestris and Betula

133 pubescens occurred occasionally. At spruce forest site S4, V. myrtillus was most abundant among

134 the dwarf shrubs and feather mosses together with Sphagnum mosses were common. At the pine

135 forest sites $\mathrm{S} 2$ and $\mathrm{S} 3$, dwarf shrubs dominated the vegetation on the forest floor, with $C$.

136 vulgaris and $V$. myrtillus being the most frequent species. Feather mosses and lichens occurred in

137 patches in between.

139 Charcoal analysis and dating

140 We kept the soil samples deep frozen in plastic bags until analysis in the laboratory. Here, 141 the samples were first oven dried at $80-105^{\circ} \mathrm{C}$ (Termaks series TS 8000) and then searched for 142 macroscopic charcoal (longest axis $\geq 0.5 \mathrm{~mm}$ ) using a magnifying lamp (4x magnification). For

143 each soil sample, the charcoal mass was then determined using an analytical scale (Sartorius

144 ED224S). Our manual hand-picking approach inevitably results in an underestimation of the size

145 of the charcoal pool as micro-charcoal is left out. However, as the microscopic fraction typically

146 make up only minor part of the charcoal pool in Scandinavian boreal forest soils (Ohlson et al.

147 2009), we are confident that our estimates give a realistic picture of the pool size. Twelve

148 charcoal fragments from sites S2 and S4 were selected for radiocarbon dating according to the

149 following procedure: four fragments were selected from one of the soil samples, and from

150 another two samples from the same block, one fragment each was selected. From another block,

151 we chose two soil samples and then selected one and two charcoal fragments from them, 
152 respectively. From each of the remaining three blocks, a single piece of charcoal was selected.

153 This selection procedure rendered 24 charcoal fragments which were sent to the National

154 Laboratory for 14C dating at the Norwegian University of Science and Technology for

155 preparation, and subsequently AMS radiocarbon dated at the Tandem Laboratory at Uppsala

156 University. Calibrated ages were determined with CALIB (Stuiver and Reimer 1993) (calibrated

157 age ranges at $1 \mathrm{SD})$. Prior to dating, the tree species from which the charcoal fragment had been

158 derived (hereafter called "parent tree species") was determined by studying the wood anatomy

159 under a microscope (Schweingruber 1990). Additionally, 153 charcoal fragments were

160 botanically identified, yielding a total number of 177 botanically identified fragments (60 and 59

161 from the sites with radiocarbon dates (S2 and S4, respectively) and 28 and 30 fragments from the

162 other two sites (S1 and S3, respectively).

163

164 Data on geographical position, vegetation, and forest density

165 We obtained additional information about the sample sites by recording the vegetation

166 composition and determining the basal area of the forest in each block with an angle gauge. We

167 recorded the basal area for the major tree species present (i.e. P. sylvestris, P. abies and B.

168 pubescens) and used it as an indicator of tree density and relative differences in the amounts of

169 fuel. The geographical position of each block was determined in the field with a handheld GPS, 170 and the position of the samples in the blocks was mapped.

\section{Statistics}

173 We used a split-plot ANOVA with site as the main plot-factor and block as the sub-plot

174 factor, to test whether amounts of charcoal (log-transformed) differed significantly between sites. 
175 Visual inspection of the residuals showed that the data met the assumptions of the model. The 176 split-plot ANOVA was followed by a Tukey's test to determine whether contrasts between

177 individual sites was significantly different. These calculations were performed with the R-

178 software for statistical computing (R Development Core Team 2011).

179 In order to check for spatial structure in the amounts of charcoal we calculated a

180 standardized omnidirectional semivariogram (Rossi et al. 1992) with the help of the R-software

181 and the package geoR, version 1.6-33 (Ribeiro Jr. and Diggle 2001). X and Y coordinates for the

182 samples were found with the help of the GPS coordinates of the sample blocks taken in the field

183 and maps indicating the position of each sample within the block. Prior to calculating the

184 semivariogram, the charcoal mass data were zero-skewness transformed in order to achieve

185 homoscedasticity and ranged on a scale between 0 and 1, see Ohlson et al. (2006) for further 186 details concerning the method used.

188 Results

189 Overall, the amount of charcoal in the soil samples averaged $269 \pm 40( \pm 1 \mathrm{SE}) \mathrm{g} \mathrm{m}^{-2}$ with 190 a pronounced variation among the individual soil samples. The largest amount, $2108 \mathrm{~g} \mathrm{~m}^{-2}$, was 191 found in the pine forest at Site 3, and 20 samples (i.e. one fifth of the samples) did not contain 192 any macroscopic charcoal. Figure 2 shows the amounts of macroscopic charcoal in soil samples 193 originating from geographically fixed positions, and our results show that there was no

194 significant spatial structure in the data, although there was a tendency for weak structure in the 195 data over fine scales (meter scale, similar amounts in neighboring samples). This was confirmed 196 by the semivariogram (Figure 3, distance classes between c. 1.5 and $12 \mathrm{~m}$ ), which also showed 197 weak spatial structure at the between-site scale (c. $200 \mathrm{~m}$ ). The average amount of macroscopic 
198 charcoal differed significantly among sites $(F=3.95 ; \mathrm{df}=3,16 ; P=0.027$, split-plot ANOVA)

199 from the spruce forest site S4 with $131 \pm 49$ to $411 \pm 111 \mathrm{~g} \mathrm{~m}^{-2}$ at the pine forest site S3 (Table

200 1). Site $S 3$ and site $S 4$ were the only sites that were significantly different from one another

201 according to the post-hoc Tukey's test $(P=0.004)$. A further indication of the difference

202 between the two forest types was that $34 \%$ of the soil samples from the spruce forests lacked

203 macroscopic charcoal, while this was the case for only $6 \%$ of samples from the pine forests (see

204 Fig. 2). However, the dissimilarity in the size of the charcoal pool was not exclusively driven by

205 forest type as there was no significant difference between spruce site S1 and pine site S2 (Table

$2061 ; P=0.999$, Tukey's test).

207 Generally, forest density (i.e. the basal area) was higher in the spruce forest than in the

208 pine forest (S1 and S4, Table I), but there was no clear relationship between the amount of

209 macroscopic charcoal $\left(\mathrm{g} \mathrm{m}^{-2}\right)$ in the soil and forest density (Figure 4).

210 The AMS radiocarbon dates of charcoal fragments from two of the sites (S2 and S4,

211 Table II and Figures 5 and 6) revealed that most of the charcoal particles were younger than

212 about 1100 cal. yr BP (c. 850 cal. yr AD). However, some particles were much older; three dated

213 back to between c. 2300 and 2600 cal. yr BP, and two were about 5000- and 8000 years old,

214 respectively (Table 2). At site S2, more than half of the dated charcoal particles originated from

215 broadleaved species, while more than half of the dated charcoal fragments originated from pine

216 at site S4. However, the majority of the charcoal particles from this site either dated back to the

217 period between c. 300 and 500 cal. yr BP or between c. 900 and 1100 cal. yr BP. This was also

218 the case for the dated charcoal particles from site S2, although their ages were slightly more

219 variable as compared to those from site S4 (Table 2). Several of the dated charcoal particles, 
220 especially from site S2, originated from the time period covered by the dendrochronological 221 analysis of the fire history in the area (i.e. AD 1335 to present, see Storaunet et al. 2013).

222 Many of the dated charcoal particles originated from fires occurring after the

223 establishment of spruce in the area, see Kasin et al. (2013), i.e. nine out of twelve particles at 224 site S2, and four out of twelve at site S4 (Table 2). Intriguingly, spruce charcoal pre-dated the 225 approximate timing of spruce establishment by about 400 years as determined by pollen analysis 226 in Kasin et al. (2013). That there were multiple and even aged charcoal particles from single soil 227 samples indicates that a number of particles, and perhaps the majority were likely to have been 228 produced by the same fire events (or a few events that were adjacent in time), see Table 2. At all sites the majority of charcoal fragments originated from Scots pine, with the 230 proportion of pine charcoal particles reaching a maximum value (c. $70-80 \%)$ in present-day 231 spruce forest sites (Fig. 5). Only two out of the 177 charcoal particles that were identified to 232 species originated from spruce, and they were both selected from one soil sample from present233 day spruce forest location S4. According to their similar radiocarbon dates (Table 2) they may 234 even have originated from the same tree. Moreover, there was more charcoal from broad leaved 235 species in the soil samples from today's pine forest sites, with charcoal originating from Sorbus 236 aucuparia being exclusive for this forest type. In this context, the occurrence of broad-leaf 237 charcoal may indicate a prevalence of surface fires in the contemporary pine forests.

238 To summarize our results, Fig. 6 shows the size, age and composition of the charcoal 239 pool, including its spatial and temporal variation in the mineral soil samples.

\section{Discussion}

\section{Charcoal amount and production rates}


The average charcoal mass of 131 to $411 \mathrm{~g} \mathrm{~m}^{-2}$ at the four sites is within the range of what

244 others have found in their studies of Scandinavian boreal forest sites (Ohlson et al. 2009; Ohlson

245 et al. 2013). In the latter study, conducted $100 \mathrm{~km}$ away from our study area, it was found that

246 there was a positive relationship between basal area of present-day forest stands and the amount

247 of charcoal in the soil, supporting findings that forest density and hence the amount of biomass

248 present at a given site is an important factor determining the amount of charcoal that can be

249 produced locally (Carcaillet and Talon 2001). However, in our present study we did not find

250 such a relationship. In fact, the opposite was the case with the soil charcoal pool being smallest

251 at spruce forest site S4 (Table 1), where the basal area was the largest among the four sites. This

252 indicates that other site-specific processes that have occurred in rather recent time may have

253 weakened the relationship between the size of the soil charcoal pool and the structure and

254 composition of today's forests. Examples of such processes are human land use in the form of

255 logging and use of fire to improve grazing qualities in the forests (see Storaunet et al. 2013;

256 Blanck et al. 2013). This lack of correlation could also be found for the peat soil charcoal pool in

257 the present forest landscape, which has been described in detail by Kasin et al. (2013). Moreover,

258 Kasin et al. (2013) found that there was no relationship between the amounts of charcoal in the

259 peat and in the bordering mineral soil, emphasizing that properties linked to specific biotopes

260 (e.g. hydrology and vegetation cover) contribute to variation in charcoal amounts at spatial scales

261 over a few tens of meters. This high degree of spatial variation in the size of the charcoal pool is

262 not only driven by the difference between peat and mineral soils as there was also considerable

263 spatial variation within the same soil type, i.e. the mineral soil in this study (Table 1 and Figure

264 2). Here, factors such as translocation after primary deposition, e.g. through surface processes 
265 (Scott and Damblon 2010), soil mixing (Gavin 2003), or variation in fuel amounts (Ohlson et al. 266 2013), affect the spatial and temporal dynamics of the charcoal pool.

267 Our geostatistical analysis revealed that the size of the charcoal pool was weakly spatially 268 structured at fine spatial scales (1 to $12 \mathrm{~m}$ ), but the fact that the size of the charcoal pool differed 269 significantly among sites (i.e. between sites S3 and S4) indicates that the pool was also spatially 270 structured at the broader between-site scale. That the soil charcoal pool is spatially structured 271 across fine spatial scales is corroborated by (Gavin et al. 2003b) and Touflan and Talon (2009) in 272 their studies from Canada and the French Southern Alps, respectively. Interestingly, despite 273 variation in charcoal amounts among sites, the proportions of the different tree species from 274 which the charcoal was derived showed little variation (see Table 2), suggesting that past forests

275 had rather similar tree species compositions. High amounts of the same charcoal species across 276 fine spatial scales may also be explained by the possibility of hitting the same burned log 277 multiple times, or small scale topography variation (e.g. in depressions, on the foot of slopes), 278 leading to the gathering of charcoal particles with a common origin.

\section{Spruce establishment}

The establishment of spruce has been shown to alter the fire regime and cause a decline in

282 fire frequency, or even cessation of fire occurrence in subdued topographic settings (Ohlson et al.

283 2011; Tryterud 2003). Consequently, the production of new charcoal from spruce should be

284 limited. Our results show that this was the case as spruce charcoal was only found in a single

285 sample from spruce forest site S4. An explanation for the general scarcity of spruce charcoal may

286 be that the stand scale history of spruce has been too short in order to provide a measurable effect

287 on the soil charcoal. As a major part of the soil charcoal pool at spruce forest sites was 
288 comprised of charcoal derived from Scots pine, it would be natural to presume that most of this 289 charcoal should originate from the time before spruce establishment. However, this can not be

290 the case due to the generally young charcoal particles (this study) and the fire history of the

291 forest landscape, as documented by Storaunet et al. (2013) and Kasin et al. (2013). According to 292 dendrochronological analysis of fire scars by Storaunet et al. (2013) and Blanck et al. (2013), the

293 study sites have been affected by several fire events during the last 500 years, when spruce were

294 present in the area (Kasin et al. 2013). However, these two studies suggest that the majority of

295 these fires were local low-intensity fires that were small in size, and probably caused by human

296 land use (Blanck et al. 2013), thus producing only minor amounts of charcoal. A further

297 explanation for the general lack of charcoal from spruce can be that resinous pine wood may

298 preserve longer after charring than does softer spruce wood. Here, it should though be noted that

299 there is a complex relationship between the presence of Norway spruce and fire activity

300 (Bradshaw et al. 2010), which is corroborated by Brown and Giesecke (2014), who found high

301 occasional charcoal deposition rates after the local establishment of spruce in central Sweden,

302 which reflect large and/or severe burns in the forest landscapes. However, Brown and Giesecke

303 (2014) analyzed lake sedimentary charcoal records that are not spatially precise as they collect

304 charcoal that has been transported from terrestrial fire source areas (see e.g. Higuera et al. 2007;

305 Ohlson et al. 2013), and it is thus not possible to conclude that fire has been locally and in situ 306 present in forests dominated by spruce.

308 Charcoal age and degradation rates

309 It is well known that charcoal degradation rates are dependent on the properties of the 310 charcoal itself, environmental factors and recurring fires (Baldock and Smernik 2002; Gundale 
311 and DeLuca 2006; Kasin and Ohlson 2013; Preston and Schmidt 2006; Santin et al. 2013;

312 Tinkham 2016). Due to radiometric- and inbuilt-age errors (Gavin 2001; Stuiver and Reimer

313 1993), the exact date for a fire event in which wood charcoal was formed cannot be determined

314 by radiocarbon dating of charcoal. The inbuilt age error can be substantial in some ecosystems,

315 i.e. several hundred years (Gavin 2001), but we believe it to be much smaller in the case of some

316 of our samples, see de Lafontaine and Payette (2012). The main reason for this is that many of

317 the dated particles originated from broad leaved tree species that are short lived and that litter

318 from these species decay relatively rapid. Even if the inbuilt age error may have been larger in

319 some of our dated particles, many of the fire events, in which they were produced, could still

320 correspond to fires documented by the dendrochronological analysis in Storaunet et al. (2013).

321 Interestingly, charcoal from this time-period was nearly absent from the mires adjacent to the

322 soil sample sites (Kasin et al. 2013), supporting the assumption that the majority of the charcoal

323 produced during the last centuries was left behind by a fine-scale mosaic of low intensity fires.

324 Intriguingly, one of the dated charcoal particles from site S2 was even younger than the latest

325 fire dated through the tree-ring analysis (Table 2, TRa - 3638, Younger than AD 1890).

326 Presupposing that our charcoal dates are representative for the mineral soil charcoal pool

327 in our study landscape, this pool must be dominated by charcoal that is younger than about 1200

328 years (see Table 2). However, fires have occurred at these sites throughout millennia (Kasin et al.

329 2013). For example, charcoal records from the peatland adjacent to site S2 reveal abundant

330 occurrences of charcoal in the peat layers originating from the time-period between c. 3000 to

3316000 cal. yr BP. If mineral soil charcoal was not decomposed, or lost in recurrent fires, charcoal

332 from these older fires ought to be more abundant in our mineral soil samples. Consequently, our

333 data contradicts de Lafontaine and Asselin (2011), who proposed that macroscopic soil charcoal 
334 particles are generally stable over millennia and should thus not be lost through degradation.

335 Numerous recent studies have focused on charcoal degradation rates, but to the best of our

336 knowledge, only few studies have estimated charcoal consumption by recurring fires, i.e. Santin

337 et al. (2013) and Tinkham et al. (2016). Interestingly, even though recurring fires may have the

338 potential to consume a major part of the pyrogenic soil charcoal, these two studies show that

339 only a minor part is consumed during recurring fire events, which in turn implies that parts of the

340 charcoal pool undergo rapid re-mineralization and degradation (see e.g. Ascough et al. 2011;

341 Kasin and Ohlson 2013; Singh et al. 2012; Zimmermann et al. 2012). Our present data

342 corroborate rapid degradation, and thus provide support for Ohlson and Tryterud (2000),

343 Czimczik et al. (2005) and Ohlson et al. (2009), who have indicated that the pyrogenic carbon

344 pool in boreal forest soils is both younger and smaller in size than what could be anticipated if

345 the soil charcoal should be truly recalcitrant. However, charcoal and other forms of pyrogenic

346 carbon are chemically and physically highly heterogenic (Schmidt and Noack 2000; Rumpel et

347 al. 2011), and incompletely pyrolysed materials are more readily decomposed than materials that

348 are completely pyrolysed (Knicker 2011; Naisse et al. 2013; Wieder et al. 2013). This means that

349 a large proportion of for example incompletely pyrolysed charcoal may be lost in short time after

350 a fire, while some proportions are very recalcitrant and can survive over several millennia due to

351 complete pyrolysis and permineralization, i.e. a concealment of the anatomical wood structures

352 by mineral infilling inside the cavities (see de Lafontaine et al. 2011). In this context, it should

353 also be mentioned that it is likely our focus on large macroscopic charcoal has contributed to an

354 underestimation of the age of the charcoal pool because charcoal particle size will inevitably

355 decline over time by erosion and other physical and biological processes (e.g. Czimczik and

356 Masiello 2007; Preston and Schmidt 2009; Rumpel et al. 2006). Moreover, given that we had 
357 used a chemical method instead of our hand-picking to quantify the size of the charcoal pool, it is 358 very probable that our results would have been somewhat different as it is well documented that 359 different pyrogenic carbon quantification methods deliver different results (Hammes et al. 2007;

360 Quénéa et al. 2006; Schmidt and Noack 2000).

361

362 


\section{Conclusions}

364 Even though the size of the charcoal pool was highly variable with a range from 0 to

$3652108 \mathrm{~g} \mathrm{~m}^{-2}$, it was only weakly spatially structured at two different scales, i.e. a fine meter scale,

366 and at a between-site $100 \mathrm{~m}$ scale. Data obtained by botanical identification and dating of

367 charcoal particles suggest that fine scale variation may arise from patterns in the pre-fire charcoal

368 stock, e.g. positions of trees and logs on the ground, while the large scale variations is likely to

369 originate from idiosyncratic differences among sites. There was no correlation between the size

370 and the composition of the charcoal pool and today's forests composition and density. This is

371 likely due to recent human land use, such as logging and use of fire, which have determined

372 today's forest structure and composition. A comparison of the age distribution of the

373 macroscopic charcoal pool with the local dendrochronologically determined fire history indicates

374 that this charcoal size fraction is lost from the soil charcoal pool at a millennial time scale.

\section{Acknowledgements}

377 We thank Ole Wiggo Røstad and Barbro Dahlberg for help in the field and at the

378 laboratory. We are also grateful to Rune Halvorsen for geostatistical advice and The National

379 Laboratory for ${ }^{14} \mathrm{C}$ dating at the Norwegian University of Science and Technology, Trondheim, 380 for funding a major part of the AMS radiocarbon dating. 


\section{References}

Ascough, P.L., Bird, M.I., Francis, S.M., Thornton, B., Midwood, A.J., Scott, A.C., and Apperley, D. 2011. Variability in oxidative degradation of charcoal: Influence of production conditions and environmental exposure. Geochim. Cosmochim. Ac. 75(9): 2361-2378. doi:10.1016/j.gca.2011.02.002.

Baldock, J.A., and Smernik, R.J. 2002. Chemical composition and bioavailability of thermally altered Pinus resinosa (Red pine) wood. Org. Geochem. 33(9): 1093-1109. doi:10.1016/s0146-6380(02)00062-1.

Blanck, Y.-L., Rolstad, J., and Storaunet, K.O. 2013. Low- to moderate-severity historical fires promoted high tree-growth in a boreal Scots pine forest in Norway. Scand. J. For. Res. 28(2): 126-135. doi:10.1080/02827581.2012.706635

Bradshaw, R.H.W., Lindbladh, M., and Hannon, G. 2010. The role of fire in southern Scandinavian forests during the late Holocene. Int. J. Wildland Fire, 19(3): 1040-1049. doi:10.1071/WF09108

Brown, K.J., and Giesecke, T. 2014. Holocene fire disturbance in the boreal forest of central Sweden. Boreas, 43(3): 639-651. doi:10.1111/bor.12056

Carcaillet, C. 1998. A spatially precise study of Holocene fire history, climate and human impact within the Maurienne valley, North French Alps. J. Ecol. 86(3): 384-396. doi:10.1046/j.1365-2745.1998.00267.x.

Carcaillet, C., and Talon, B. 2001. Soil carbon sequestration by holocene fires inferred from soil charcoal in the dry French Alps. Arct. Antarct. Alp. Res. 33(3): 282-288. doi: $10.2307 / 1552235$. 
Clark, J.S. 1988. Particle motion and the theory of charcoal analysis - source area, transport, deposition, and sampling. Quaternary Res. 30(1): 67-80. doi:10.1016/0033-5894(88)900889.

Couillard, P.-L., Payette, S., and Grondin, P. 2013. Long-term impact of fire on the high-altidude balsam fir (Abies balsamea) forest in south-central Quebec deduced from soil charcoal. Can. J. For. Res. 43(2): 188-199. doi:10.1139/cjfr-2012-0414.

Czimczik, C.I., and Masiello, C.A. 2007. Controls of black carbon storage in soils. Global Biochem. Cy. 21(3): GB3005. doi:10.1029/2006GB002798.

Czimczik, C.I., Schmidt, M.W.I., and Schulze, E.D. 2005. Effects of increasing fire frequency on black carbon and organic matter in Podzols of Siberian Scots pine forests. Eur. J. Soil. Sci. 56(3): 417-428. doi:10.1111/j.1365-2389.2004.00665.x.

de Lafontaine, G., and Asselin, H. 2011. Soil charcoal stability over the Holocene across boreal northeastern North America. Quaternary Res. 76(2): 196-200.

doi:10.1016/j.yqres.2011.06.006.

de Lafontaine, G., Couillard, P.-L., and Payette, S. 2011. Permineralization process promotes preservation of Holocene macrofossil charcoal in soils. J. Quaternary Sci. 26(6): 571-575. doi:10.1002/jqs.1529.

de Lafontaine, G., and Payette, S. 2012. Long-term fire and forest history of subalpine balsam fir (Abies balsamea) and white spruce (Picea glauca) stands in eastern Canada inferred from soil charcoal analysis. Holocene 22(2): 191-201. doi:10.1177/0959683611414931.

Flannigan, M., Stocks, B., Turetsky, M., and Wotton, M. 2009. Impacts of climate change on fire activity and fire management in the circumboreal forest. Glob. Change Biol. 15(3): 549-560. doi:10.1111/j.365-2486.2008.01660.x. 
Gavin, D.G. 2001. Estimation of inbuilt age in radiocarbon ages of soil charcoal for fire history studies. Radiocarbon, 43(1): 27-44.

Gavin, D.G. 2003. Forest soil disturbance intervals inferred from soil charcoal radiocarbon dates. Can. J. For. Res. 33(12): 2514-2518. doi:10.1139/x03-185.

Gavin, D.G., Brubaker, L.B., and Lertzman, K.P. 2003a. An 1800-year record of the spatial and temporal distribution of fire from the west coast of Vancouver Island, Canada. Can. J. For. Res. 33(4): 573-586. doi:10.1139/x02-196.

Gavin, D.G., Brubaker, L.B., and Lertzman, K.P. 2003b. Holocene fire history of a coastal temperate rain forest based on soil charcoal radiocarbon dates. Ecology, 84(1): 186-201. doi:10.1890/0012-9658(2003)084[0186:HFHOAC]2.0.CO;2.

Giesecke, T., and Bennett, K.D. 2004. The Holocene spread of Picea abies (L.) Karst. in Fennoscandia and adjacent areas. J. Biogeogr. 31(9): 1523-1548. doi:10.1111/j.13652699.2004.01095.x.

Gundale, M.J., and DeLuca, T.H. 2006. Temperature and source material influence ecological attributes of ponderosa pine and Douglas-fir charcoal. For. Ecol. Manage. 231(1-3): 86-93. doi:http://dx.doi.org/10.1016/j.foreco.2006.05.004.

Hammes, K. et al., 2007. Comparison of quantification methods to measure fire-derived (black/elemental) carbon in soils and sediments using reference materials from soil, water, sediment and the atmosphere. Global Biochem. Cy. 21(3): GB3016. doi:10.1029/2006GB002914.

Hart, S. and Luckai, N. 2013. Charcoal function and management in boreal ecosystems. J. Appl. Ecol. 50: 1197-1206. doi:10.1111/1365-26644. 2136 
Higuera, P.E., Peters, M.E., Brubaker, L.B., and Gavin, D.G. 2007. Understanding the origin and analysis of sediment-charcoal records with a simulation model. Quaternary Sci. Rev. 26: (1314): 1790-1809. doi:10.1016/j.quascirev.2007.03.010.

Higuera, P.E., Sprugel, D.G., and Brubaker, L.B. 2005. Reconstructing fire regimes with charcoal from small-hollow sediments: a calibration with tree-ring records of fire. Holocene, 15(2): 238-251. doi:10.1191/0959683605hl789rp.

Jacobson Jr, G.L., and Bradshaw, R.H.W. 1981. The selection of sites for paleovegetational studies. Quaternary Res. 16(1): 80-96. doi:10.1016/0033-5894(81)90129-0.

Kane, E., Hockaday, W., Turetsky, M., Masiello, C., Valentine, D., Finney, B., and Baldock, J. 2010. Topographic controls on black carbon accumulation in Alaskan black spruce forest soils: implications for organic matter dynamics. Biogeochemistry, 100(1): 39-56. doi:10.1007/s10533-009-9403-z.

Kasin, I., Blanck, Y., Storaunet, K.O., Rolstad, J., and Ohlson, M. 2013. The charcoal record in peat and mineral soil across a boreal landscape and possible linkages to climate change and recent fire history. Holocene 23(7): 1050-1063. doi:10.1177/0959683613479678.

Kasin, I., and Ohlson, M. 2013. An experimental study of charcoal degradation in a boreal forest. Soil Biol. Biochem. 65: 39-49. doi:10.1016/j.soilbio.2013.05.005.

Knicker, H. 2011. Pyrogenic organic matter in soil: Its origin and occurrence, its chemistry and survival in soil environments. Quatern. Int. 243(2): 251-263. doi:10.1016/j.quaint.2011.02.037.

Lehmann, J., Rillig, M.C., Thies, J., Masiello, C.A., Hockaday, W.C., and Crowley, D. 2011. Biochar effects on soil biota - A review. Soil. Biol. Biochem. 43 (9): 1812-1836. doi:10.1016/j.soilbio.2011.04.022 
Lehmann, J., Skjemstad, J., Sohi, S., Carter, J., Barson, M., Falloon, P., Coleman, K., Woodbury, P., and Krull, E. 2008. Australian climate-carbon cycle feedback reduced by soil black carbon. Nature Geosci. 1(12): 832-835. doi:10.1038/ngeo358.

Lertzman, K., Gavin, D., Hallett, D., Brubaker, L., Lepofsky, D., and Mathewes, R. 2002. LongTerm Fire Regime Estimated from Soil Charcoal in Coastal Temperate Rainforests. Conserv. Ecol. 6(2): 5.

Lid, J., and Lid, D.T. 2005. Norsk flora. Samlaget, Oslo.

Moen A (1999) National Atlas of Norway - Vegetation, Hønefoss: Norwegian Mapping Authority.

Naisse, C., Alexis, M., Plante, A., Wiedner, K., Glaser, B., Pozzi, A., Carcaillet, C., Criscuoli, I., and Rumpel, C. 2013. Can biochar stability be assessed with chemical methods? Org. Geochem. 60: 40-44. doi:10.1016/j.orggeochem.2013.04.011.

Norwegian Meteorological Institute. 2012. Daily and monthly normal values, normal period 1961-1990. Available from www.met.no [accessed 22.05.2012].

Ohlson, M., Brown, K.J., Birks, H.J.B., Grytnes, J.-A., Hörnberg, G., Niklasson, M., Seppä, H., and Bradshaw, R.H.W. 2011. Invasion of Norway spruce diversifies the fire regime in boreal European forests. J. Ecol. 99(2): 395-403. doi:10.1111/j.1365-2745.2010.01780.x.

Ohlson, M., Dahlberg, B., Økland, T., Brown, K.J., and Halvorsen, R. 2009. The charcoal carbon pool in boreal forest soils. Nature Geosci. 2(10): 692-695. doi:10.1038/ngeo617.

Ohlson, M., Korbøl, A., and Økland, R.H. 2006. The macroscopic charcoal record in forested boreal peatlands in southeast Norway. Holocene, 16(5): 731-741. doi:10.1191/0959683606h1955rp. 
Ohlson, M., and Tryterud, E. 2000. Interpretation of the charcoal record in forest soils: forest fires and their production and deposition of macroscopic charcoal. Holocene, 10(4): 519-525. doi:10.1191/095968300667442551.

Ohlson, M., Kasin, I., Wist, A.N. and Bjune, A.E. 2013. Size and spatial structure of the soil and lacustrine charcoal pool across a boreal forest watershed. Quaternary Res. 80 (3): 417-424. doi:10.1016/j.yqres.2013.08.009.

Økland, T. 1996. Vegetation-environment relationships of boreal spruce forests in ten monitoring reference areas in Norway. Sommerfeltia, 22: 1-349.

Patterson, W.A., Edwards, K.J., and Maguire, D.J. 1987. Microscopic charcoal as a fossil indicator of fire. Quaternary Sci. Rev. 6(1): 3-23. doi:10.1016/0277-3791(87)90012-6.

Preston, C.M. 2009. Fire's black legacy. Nature Geosci. 2(10): 674-675. doi:10.1038/ngeo642.

Preston, C.M., and Schmidt, M.W.I. 2006. Black (pyrogenic) carbon: a synthesis of current knowledge and uncertainties with special consideration of boreal regions. Biogeosciences, 3(4): 397-420.

Quénéa, K., Derenne, S., Rumpel, C., Rouzaud, J.-N., Gustafsson, O., Carcaillet, C., Mariotti, A., and Largeau, C. 2006. Balck carbon yields and type in forest and cultivated sand soils (Landes de Gacogne, France) as determined with different methods: Influence of change in land use. Org. Geochem. 37 (9): 1185-1189. doi:10.1016/j.orggeochem.2006.05.010.

R Development Core Team. 2011. R: A language and environment for statistical computing. R Foundation for Statistical Computing, Vienna, Austria.

Ribeiro Jr., P.J., and Diggle, P.J. 2001. geoR: A package for geostatistical analysis. R-NEWS Vol 1, No 2 . 
Rossi, R.E., Mulla, D.J., Journel, A.G., and Eldon, H.F. 1992. Geostatistical Tools for Modeling and Interpreting Ecological Spatial Dependence. Ecol. Monogr. 62(2): 277-314. doi:10.2307/2937096.

Santín, C., Doerr, S.H., Preston, C. and Bryant, R. 2013. Consumption of residual pyrogenic carbon by wildfire. Int. J. Wildland Fire, 22(8): 1072-1077. doi:10.1071/WF12190.

Santín, C., Doerr, S.H., Kane, E.S., Masiello, C.A., Ohlson, M., De la Rosa, J.M., Preston, C.M. and Dittmar, T. 2016. Towards a global assessment of pyrogenic carbon from vegetation fires. Glob. Change Biol. 22(1): 76-91. doi:10.1111/gcb.12985.

Schmidt, M.W.I., and Noack, A.G. 2000. Black carbon in soils and sediments: Analysis, distribution, implications, and current challenges. Global Biochem. Cy. 14(3): 777-793. doi:10.1029/1999GB001208.

Schmidt, M.W.I., Torn, M.S., Abiven, S., Dittmar, T., Guggenberger, G., Janssens, I.A., Kleber, M., Kogel-Knabner, I., Lehmann, J., Manning, D.A.C., Nannipieri, P., Rasse, D.P., Weiner, S., and Trumbore, S.E. 2011. Persistence of soil organic matter as an ecosystem property. Nature, 478: 49-56. doi:10.1038/nature10386.

Schweingruber, F.H. 1990. Anatomy of European woods. Birmensdorf Eidgenössische Forschungsanstalt für Wald,Schnee und Landschaft, Birmensdorf. pp. 800.

Scott, A.C. 2010. Charcoal recognition, taphonomy and uses in palaeoenvironmental analysis. Paleogeogr. Palaeocl. 291(1-2): 11-39. doi:10.1016/j.palaeo.2009.12.012.

Scott, A.C., and Damblon, F. 2010. Charcoal: Taphonomy and significance in geology, botany and archaeology. Paleogeogr. Palaeocl. 291(1-2): 1-10. doi:10.1016/j.palaeo.2010.03.044. 
Seppä, H., Alenius, T., Bradshaw, R.H.W., Giesecke, T., Heikkilä, M. and Muukkonen, P. 2009. Invasion of Norway spruce (Picea abies) and the rise of the boreal ecosystem in Fennoscandia. J. Ecol. 97(4): 629-640. doi:10.1111/j.1365-2745.2009.01505.x.

Singh, N., Abiven, S., Torn, M.S., and Schmidt, M.W.I. 2012. Fire-derived organic carbon in soil turns over on a centennial scale. Biogeosciences 9(8): 2847-2857. doi:10.5194/bg-92847-2012.

Soja, A.J., Tchebakova, N.M., French, N.H.F., Flannigan, M.D., Shugart, H.H., Stocks, B.J., Sukhinin, A.I., Parfenova, E.I., Chapin, F.S. III, and Stackhouse, P.W., Jr. 2007. Climateinduced boreal forest change: Predictions versus current observations. Global Planet. Change, 56: 274-296. doi:10.1016/j.gloplacha.2006.07.028.

Storaunet, K.O., Rolstad, J., Toeneiet, M., Blanck, Y.-1. 2013. Strong anthropogenic signal in historic forest fire regime: a detailed spatio-temporal case study from south-central Norway. Can. J. For. Res. 43(9): 836-845. doi:10.1139/cjfr-2012-0462.

Stuiver, M., and Reimer, P.J. 1993. Extended ${ }^{14} \mathrm{C}$ data base and revised CALIB $3.0{ }^{14} \mathrm{C}$ age calibration program. Radiocarbon, 35(1): 215-230.

Tallantire, P.A. 1972. Spread of spruce (Picea abies (L) Karst) in Fennoscandia and possible climatic implications. Nature, 236: 64-65. doi:10.1038/236064a0.

Talon, B. 2010. Reconstruction of Holocene high-altitude vegetation cover in the French southern Alps: evidence from soil charcoal. Holocene, 20(1): 35-44. doi:10.1177/0959683609348842.

Talon, B., Payette, S., Fillon, L., and Delwaide, A. 2005. Reconstruction of the long-term fire history of an old-growth deciduous forest in Southern Quebec, Canada, from charred wood in mineral soils. Quaternary Res. 64(1): 36-43. doi:10.1016/j.yqres.2005.03.003. 
Tinkham, W., Smith, A.M.S., Higuera, P.E., Hatten, J.A., Brewer, N.W. and Doerr, S.H. 2016. Replacing time with space: using laboratory fires to explore the effects of repeated burning on black carbon degradation. Int. J. Wildland Fire, 25(2): 242-248. doi:0.1071/WF15131.

Tinner, W., Hofstetter, S., Zeugin, F., Conedera, M., Wohlgemuth, T., Zimmermann, L., and Zweifel, R. 2006. Long-distance transport of macroscopic charcoal by an intensive crown fire in the Swiss Alps - implications for fire history reconstruction. Holocene, 16(2): 287-292. doi:10.1191/0959683606h1925rr.

Touflan, P., and Talon, B. 2009. Spatial reliability of roil charcoal analysis: The case of Subalpine Forest Soils. Ecoscience, 16(1): 23-27. doi:10.2980/16-1-3177.

Touflan, P., Talon, B., and Walsh, K. 2010. Soil charcoal analysis: a reliable tool for spatially precise studies of past forest dynamics: a case study in the French southern Alps. Holocene, 20(1): 45-52. doi:10.1177/0959683609348900.

Tryterud, E. 2003. Forest fire history in Norway: from fire-disturbed pine forests to fire-free spruce forests. Ecography, 26(2): 161-170. doi:10.1034/j.1600-0587.2003.02942.x.

Wiedner, K., Naisse, C., Rumpel, C., Pozzi, A., Wieczorek, P., and Glaser, B. 2013. Chemical modification of biomass during hydrothermal carbonization - What makes the difference, temperature or feedstock? Org. Geochem. 54: 91-100.

doi:10.1016/j.orggeochem.2012.10.006.

Zackrisson, O., Nilsson, M.-C. and Wardle, D.A. 1996. Key Ecological Function of Charcoal from Wildfire in the Boreal Forest. Oikos, 77(1): 10-19. doi:10.2307/3545580.

Zimmermann, M., Bird, M.I., Wurster, C., Saiz, G., Goodrick, I., Barta, J., Capek, P., Santruckova, H., and Smernik, R. 2012. Rapid degradation of pyrogenic carbon. Glob. Change Biol. 18(11): 3306-3316. doi:10.1111/j.1365-2486.2012.02796.x. 
Table 1. Amount of macroscopic charcoal and forest density. Figure 1 gives information about site locations in the Trillemarka-Rollagsfjell Nature reserve, SE Norway.

\begin{tabular}{llclll}
\hline $\begin{array}{l}\text { Site and } \\
\text { contemporary } \\
\text { forest type }\end{array}$ & $\begin{array}{l}\text { Average } \\
\text { amount of } \\
\text { macroscopic } \\
\text { charcoal }\end{array}$ & Median & $\begin{array}{l}\text { Min. charcoal } \\
\left(\mathrm{g} \mathrm{m}^{-2}\right)\end{array}$ & $\begin{array}{l}\text { Max. charcoal } \\
\left(\mathrm{g} \mathrm{m}^{-2}\right)\end{array}$ & $\begin{array}{l}\text { Average } \\
\text { basal area } \\
\left(\mathrm{m}^{2} \mathrm{ha}^{-1}\right)\end{array}$ \\
\hline S1 spruce & $329(85)$ & 239 & 0 & 1533 & $15(2)$ \\
S2 pine & $204(53)$ & 106 & 0 & 797 & $10(0.4)$ \\
S3 pine & $411(111)$ & 212 & 7 & 2108 & $19(2)$ \\
S4 spruce & $131(49)$ & 13 & 0 & 823 & \\
Spruce & $230(51)$ & 29 & & & \\
Pine & $308(63)$ & 152 & & & \\
All sites & $269(40)$ & 97 & & & \\
\hline
\end{tabular}

Note: Standard errors are provided in parentheses. 
Table 2. AMS radiocarbon dates and botanical origin of macroscopic charcoal from pine forest site S2 and spruce forest site S4 in the Trillemarka-Rollagsfjell Nature reserve, SE Norway. Calibrated age determined with CALIB according to Stuiver and Reimer (1993). Calibrated age ranges at 1 standard deviation $(\mathrm{SD})$.

\begin{tabular}{|c|c|c|c|}
\hline Lab. ref. & Site & Charcoal parent tree species & Calibrated age \\
\hline TRa-3637 & $\mathrm{S} 2$ & Betula sp. & AD 1040-1165 \\
\hline TRa-3638 & $\mathrm{S} 2$ & Pinus sylvestris & Y. than AD1890 \\
\hline TRa-3633 & $\mathrm{S} 2$ & Betula sp. & BC $765-515$ \\
\hline TRa-3634 & $\mathrm{S} 2$ & Pinus sylvestris or Picea abies & AD 1300-1395 \\
\hline TRa-3635 & $\mathrm{S} 2$ & Sorbus aucuparia & BC 385-205 \\
\hline TRa-3636 & $\mathrm{S} 2$ & Sorbus aucuparia & AD 1305-1400 \\
\hline TRa-3642 & $\mathrm{S} 2$ & Betula sp. & AD 1485-1635 \\
\hline TRa-3643 & $\mathrm{S} 2$ & Betula sp. & AD 1000-1025 \\
\hline TRa-3640 & $\mathrm{S} 2$ & Pinus sylvestris & AD 1430-1445 \\
\hline TRa-3641 & $\mathrm{S} 2$ & Pinus sylvestris & AD 1435-1450 \\
\hline TRa-3639 & $\mathrm{S} 2$ & Pinus sylvestris or Picea abies & BC 2905-2785 \\
\hline TRa-3644 & $\mathrm{S} 2$ & Betula sp. & AD 1185-1240 \\
\hline TRa-3647 & $\mathrm{S} 4$ & Pinus sylvestris or Picea abies & AD 1490-1640 \\
\hline TRa-3648 & $\mathrm{S} 4$ & Pinus sylvestris & AD $815-890$ \\
\hline TRa-3649 & $\mathrm{S} 4$ & Pinus sylvestris & AD 785-890 \\
\hline TRa-3650 & $\mathrm{S} 4$ & Pinus sylvestris & AD $885-970$ \\
\hline TRa-3645 & $\mathrm{S} 4$ & Pinus sylvestris or Picea abies & BC $5690-5590$ \\
\hline TRa-3646 & $\mathrm{S} 4$ & Betula sp. & AD 1475-1630 \\
\hline TRa-3656 & $\mathrm{S} 4$ & Pinus sylvestris & Y. than AD 1660 \\
\hline TRa-3652 & $\mathrm{S} 4$ & Picea abies & AD 1015-1035 \\
\hline TRa-3653 & $\mathrm{S} 4$ & Picea abies & AD 965-1010 \\
\hline TRa-3654 & $\mathrm{S} 4$ & Pinus sylvestris & BC 770-530 \\
\hline TRa-3651 & $\mathrm{S} 4$ & Pinus sylvestris & AD 780-885 \\
\hline TRa-3655 & $\mathrm{S} 4$ & Pinus sylvestris & AD 1445-1485 \\
\hline
\end{tabular}




\section{Figure captions - Kasin et al.}

Fig. 1. The study area in SE Norway (insert top-left) and locations for soil sampling at four sites in the Trillemarka-Rollagsfjell Nature reserve.

Fig. 2. Bubble plot showing the spatial distribution of charcoal mass in soil samples collected from four different $50 \times 50 \mathrm{~m}^{2}$ forest sites in the Trillemarka-Rollagsfjell Nature reserve, SE Norway. Sites 1 and 4 are spruce forests, and Sites 2 and 3 are pine forests. Note the logarithmic scale of Samples containing charcoal are marked with dots and samples without charcoal are marked with squares. See Fig. 1 for site locations in the forest landscape.

Fig. 3. Standardized semivariogram for amount of macroscopic charcoal in forest soil samples (all samples from all four sites, $n=100-$ see Fig. 1). A variable is spatially structured in distance intervals where the semivariogram values increase with increasing distance, i.e. between c. $1.5-$ 12 and $24-200 \mathrm{~m}$, respectively. However, the spatial structure in our date is weak as the semivariogram values fall within the dotted line envelope obtained by 999 permutations. Labels on the horizontal axis indicate midpoints of distance lag classes, expressed as $2^{\mathrm{n}} \mathrm{m}$. Auxiliary distance classes, expressed in m, are also added to the horizontal axis (in parenthesis), and the horizontal line on the value of 1 show the semivariance on a standardized scale that is common for the both the semivariance and the measured variable.

Fig. 4. Relationship between forest density and soil charcoal amount per block, which represents the average amount of charcoal from five soil samples at each site. 
Fig. 5. Proportion of charcoal parent tree species in soil samples from spruce and pine forests at four different sites in the Trillemarka-Rollagsfjell Nature reserve, SE Norway. "Spruce" and "Pine" below the site number indicate the present-day forest type. Note that the number of charcoal particles, from which the proportions were calculated, differ among sites, i.e. S1: $n=28$, $\mathrm{S} 2: n=60, \mathrm{~S} 3: n=30, \mathrm{~S} 4: n=59$.

Fig. 6. Schematic drawing illustrating how spatial and temporal variations in the soil charcoal pool determine the composition of charcoal in contemporary soil samples. A and B: cylindrical soil samples. The squares depict four "time windows" showing the forest floor after forest fires from the past. Occurrence of macroscopic charcoal is indicated by different lines: solid lines $=$ charcoal still present at the time of sampling; dashed lines = charcoal originally produced at a given location, but which has been lost in later fires, or through other degradation pathways. Note that the probability that locally produced charcoal has gone lost, increases over time. 
383 Fig. 1. Kasin et al.

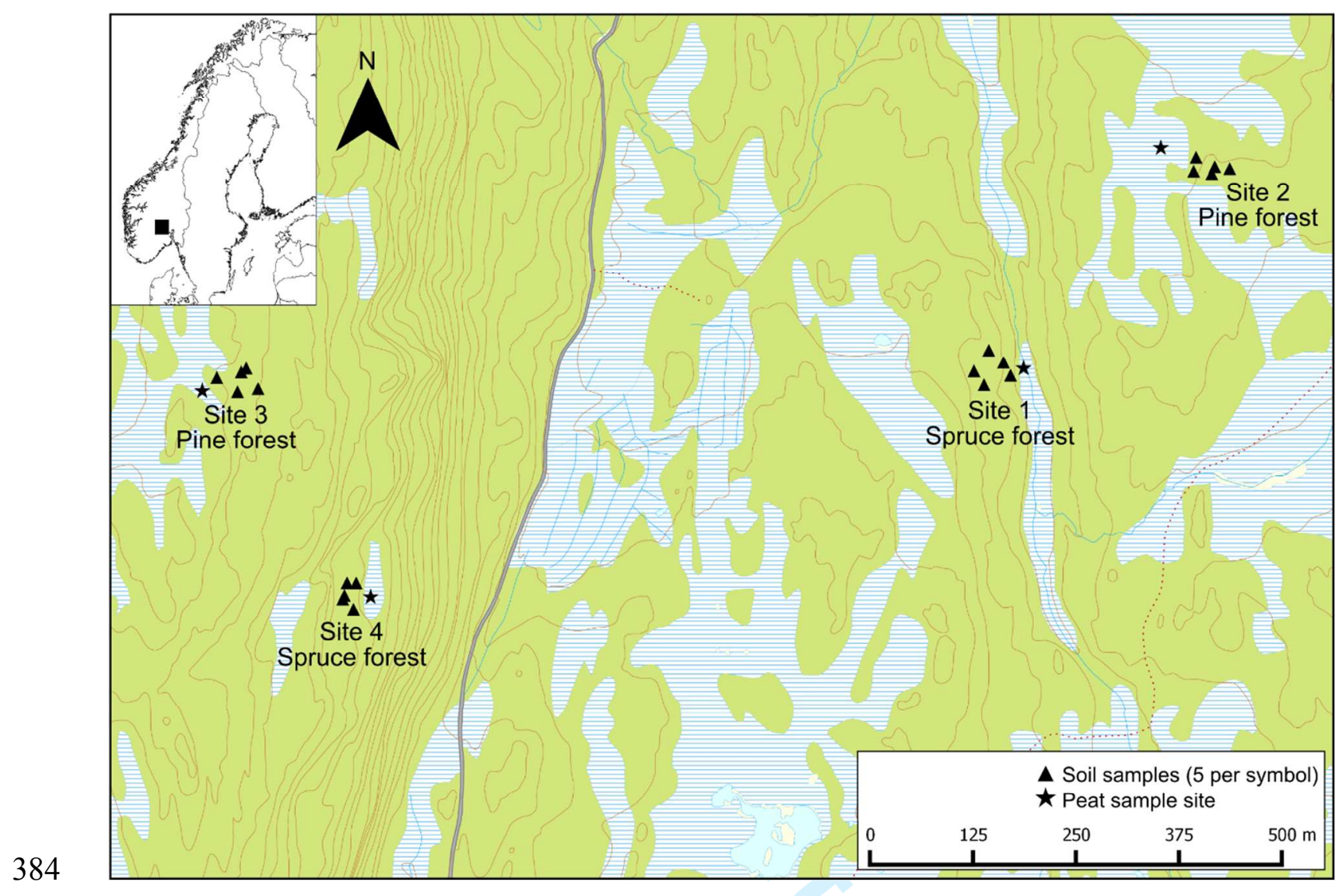

385 
387 Fig. 2. Kasin et al.

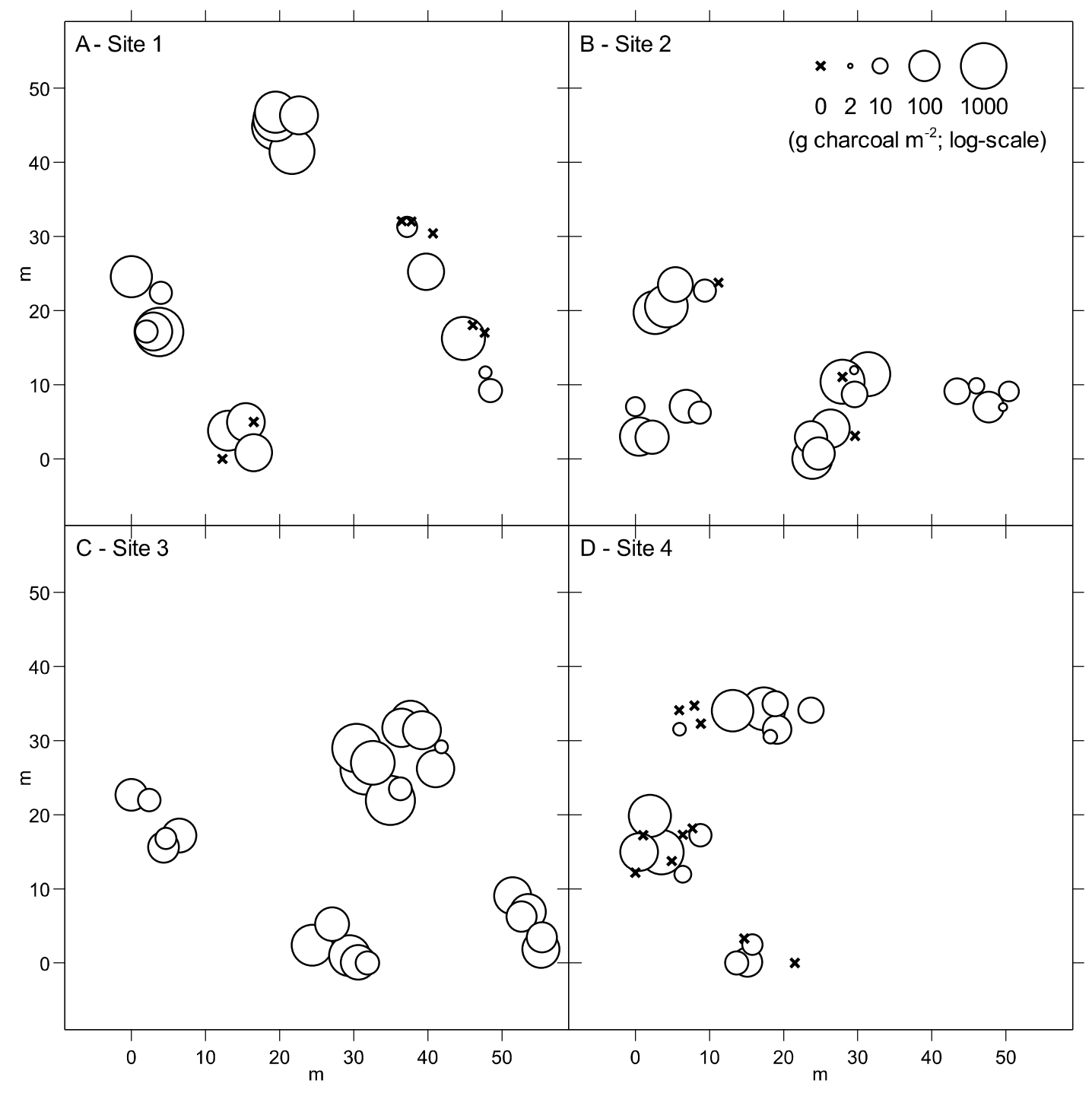

388 
390 Fig. 3. Kasin et al.

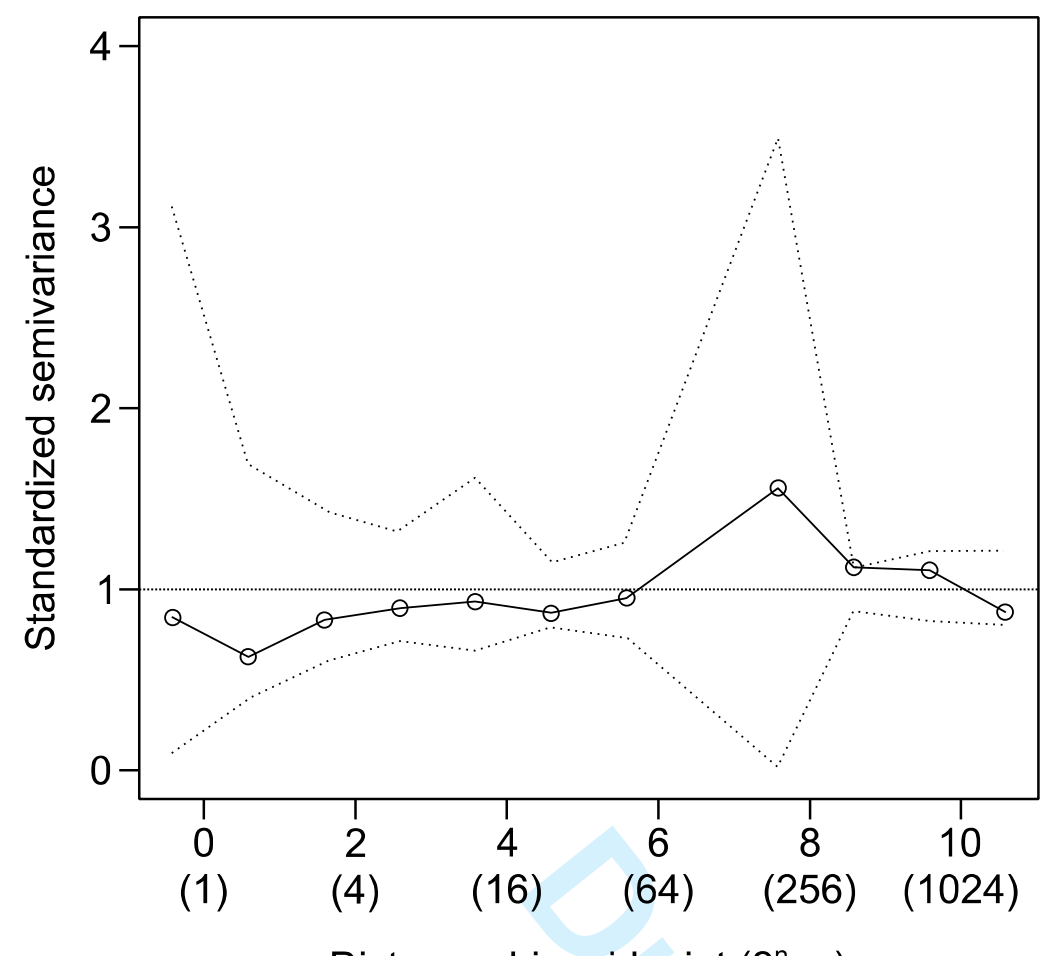

391

Distance, bin midpoint $\left(2^{n} \mathrm{~m}\right)$ 
393 Fig. 4. Kasin et al

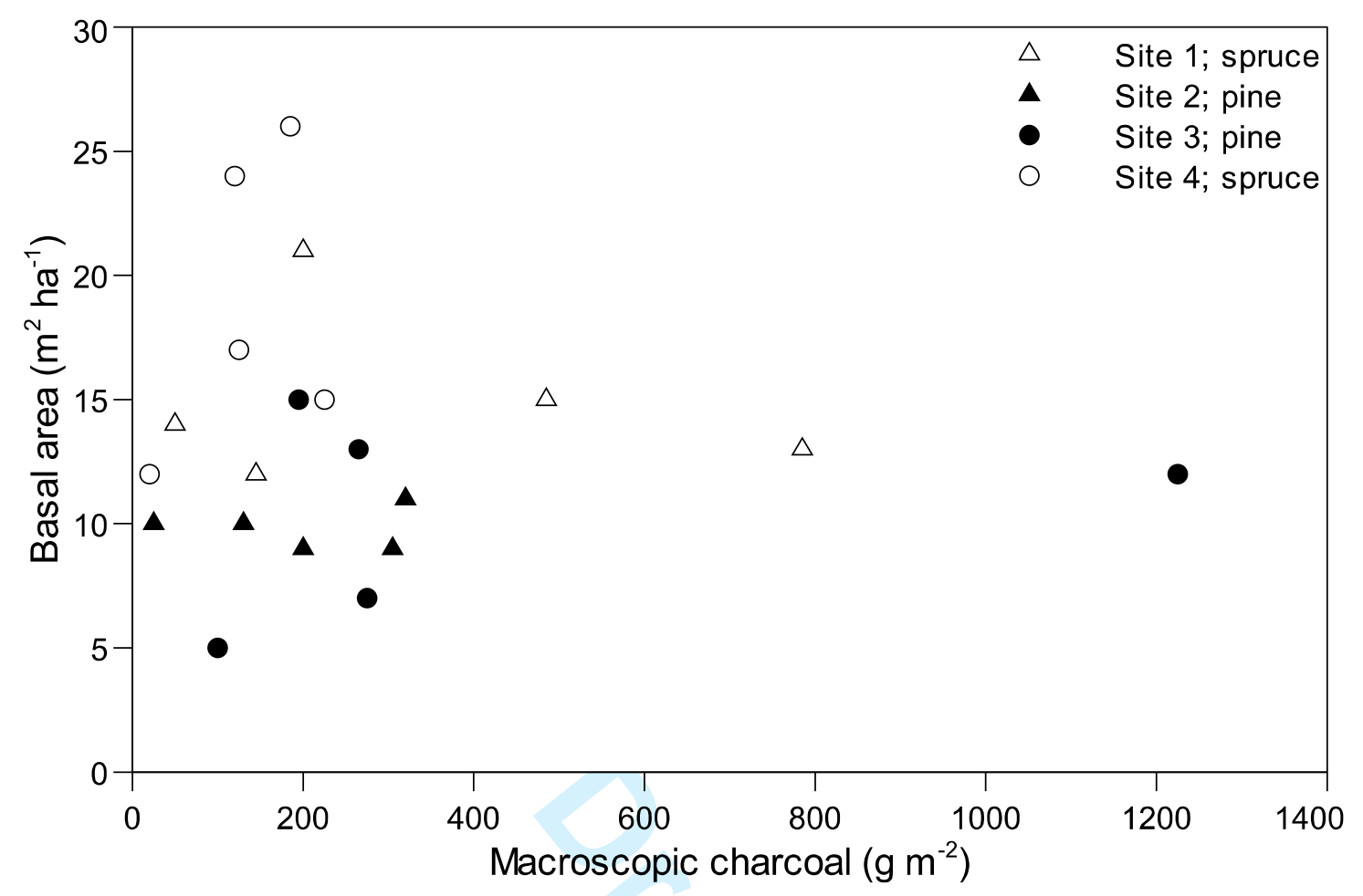

394

395

396 
397 Fig. 5. Kasin et al.

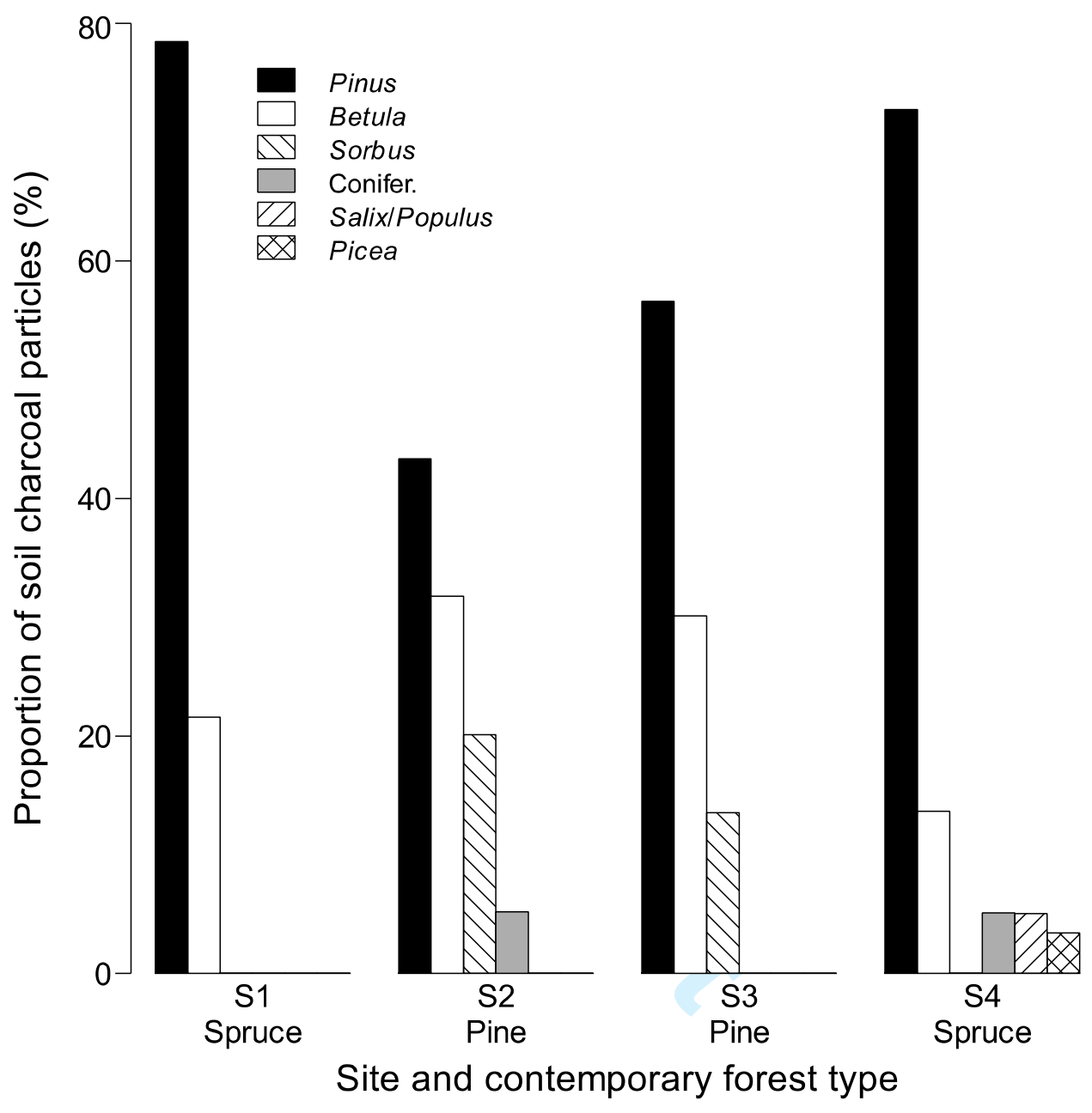


400 Fig. 6. Kasin et al.

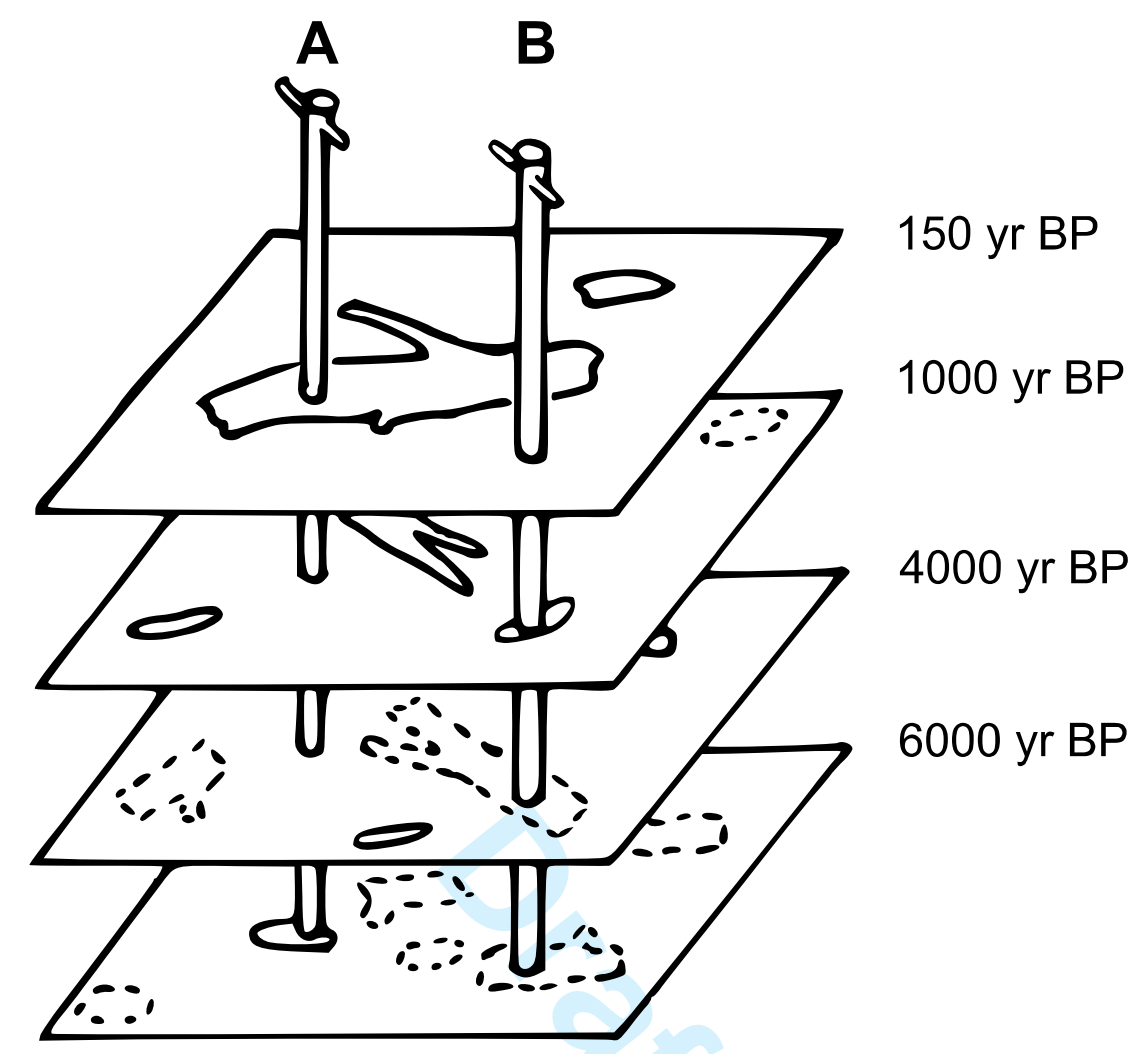

401 